\title{
Article \\ First U-Pb Detrital Zircon Ages from Kamlial Formation (Kashmir, Pakistan): Tectonic Implications for Himalayan Exhumation
}

\author{
Muhammad Qasim 1,2,3,*, Javed Iqbal Tanoli ${ }^{3, *}$, Luqman Ahmad ${ }^{3} \mathbb{D}$, Lin Ding 1,2, Qasim Ur Rehman 4 \\ and Umbreen Umber ${ }^{3}$
}

check for

updates

Citation: Qasim, M.; Tanoli, J.I.;

Ahmad, L.; Ding, L.; Rehman, Q.U.;

Umber, U. First U-Pb Detrital Zircon Ages from Kamlial Formation (Kashmir, Pakistan): Tectonic Implications for Himalayan Exhumation. Minerals 2022, 12, 298. https://doi.org/10.3390/ $\min 12030298$

Academic Editors: David Gómez-Gras and Marta Roigé

Received: 5 January 2022

Accepted: 23 February 2022

Published: 26 February 2022

Publisher's Note: MDPI stays neutral with regard to jurisdictional claims in published maps and institutional affiliations.

Copyright: (C) 2022 by the authors. Licensee MDPI, Basel, Switzerland. This article is an open access article distributed under the terms and conditions of the Creative Commons Attribution (CC BY) license (https:// creativecommons.org/licenses/by/ $4.0 /)$.
1 Key Laboratory of Continental Collision and Plateau Uplift, Center for Excellence in Tibetan Plateau Earth Sciences, Institute of Tibetan Plateau Research, Chinese Academy of Sciences, Beijing 100101, China; dinglin@itpcas.ac.cn

2 University of Chinese Academy of Sciences, Beijing 100049, China

3 Department of Earth Sciences, Abbottabad Campus, COMSATS University Islamabad, Abbottabad 22010, Pakistan; geoluqman56@gmail.com (L.A.); umbreenumber@cuiatd.edu.pk (U.U.)

4 Department of Earth Sciences, University of Haripur, Haripur 22620, Pakistan; qrehman@uoh.edu.pk

* Correspondence: qasimtanoli@itpcas.ac.cn (M.Q.); javed_iqbal@cuiatd.edu.pk (J.I.T.)

\begin{abstract}
This study reports the first-ever detrital zircon provenance investigation of sandstones of the Kamlial Formation, exposed in Kashmir Basin along the Kohala-Bagh road section (Muzaffarabad, Pakistan). Analysis of probability density plots of detrital U-Pb zircon ages displayed a major age population clustered around $\approx 400-1200$ Ma and a minor age population clustered around $\approx 1600-1900$ Ma. In addition, scattered ages existed between $\approx 2000$ and 3000 Ma. This age pattern resembled strongly the Himalayan sources, including the Tethys Himalaya, Greater/Higher Himalaya, and Lesser Himalaya. The younger ages $(<150 \mathrm{Ma})$ present in the studied samples indicated the Asian provenance. The Lesser Himalayan component ( $\approx 166-1900 \mathrm{Ma})$ was more pronounced in the 2015KM03 and 2015KM04 samples, representing the middle to the upper portion of the formation. The recycled orogen provenance of the Kamlial Formation as deduced from the sandstone petrography supports the mixed detrital zircon provenance. Considering the provenance, we propose a tectonic model that suggests that large-scale exhumation occurred in the Himalaya as a result of Panjal thrust activation during 25-14 Ma (age of Kamlial Formation), which uplifted the hinterland zone that acted as a source area that fed the foreland basin, where the Kamlial Formation deposited.
\end{abstract}

Keywords: detrital zircon provenance; Miocene sequence; Hazara-Kashmir Syntaxis; Kashmir foreland-fold belt; Northwestern Himalaya; Himalayan Exhumation

\section{Introduction}

The Himalayan fold-thrust belt and foreland basin are manifestations of the $\approx 50-55 \mathrm{Ma}$ continental collision between India and Eurasia (Figure 1A) [1]. The foreland basin sediments contain important information about paleo-tectonic processes that occurred during orogen development. An in-depth examination of sedimentary rocks of the basin enables us to find out the source of the sediments and rebuild their tectonic history [2]. Sedimentary rocks in the basin hold information about fluctuations in sea level, origins of sedimentary rocks, and the tectonic history of the basin [3]. The sedimentary archives of the foreland basins are extensively analyzed using modern techniques such as $\mathrm{U}-\mathrm{Pb}$ dating [4-8] to estimate the maximum depositional ages and constrain the sediment provenance. This is a powerful tool in identifying the precise information about the sediment provenance, which is very important in explaining the paleogeographic reconstructions of the terranes in geological history [9-11]. Furthermore, this technique has also been widely applied in constraining the timing of orogenic events such as Ophiolite obduction and final collision in 
the Himalayan orogen $[4,10]$. The Himalayan foreland basin attained significant attraction in the last three decades to address the timing and location of the initial India-Asia collision using the foreland basing sedimentary archives [1,6,7,12-16]. Following the initial collision, the mountain belts evolved continuously in response to fold-thrust belt propagation. Therefore, in this research project, an integrated approach was adopted to trace the possible provenance of the middle to late Miocene Kamlial Formation. This integrated provenance approach provides an insight to the exhumation history of the Himalayan belt and foreland basin. Tectonically, our study area is situated in the sub-Himalayas, footwall hills of MBT (Kashmir Basin) (Figure 1A-C), and part of the foreland basin.

Various researchers studied the geology of this area and classified the stratigraphy of the Kashmir basin, which consists of well-exposed outcrops of molasses sequence (Murree and Kamlial formations), Siwaliks (Chinji, Nagri, Dokh Pathan, and Soan formations), and recent alluvium. These formations are differentiated by mineralogical and lithological variations [17-22]. These formations have been studied in detail for stratigraphy, sandstone petrography, and geochemistry [23-26]. However, modern detrital zircon U-Pb age dating has only been applied to Murree Formation $[1,4,7,26]$. However, the coeval sedimentary archives of the foreland basin were extensively studied in India, Nepal, Tibet, and the eastern Himalayan syntaxial region using the traditional and as well as the modern detrital zircon techniques. This sequence is continuous along the strike in the Himalayan foreland basin and referred to as various local stratigraphic nomenclature. Its continuity throughout the foreland basin makes it an important sedimentary unit that stored the information about the hinterland tectonism. Therefore, in this study, the Kamlial Formation representing the upper molasse sequence has been selected for the first time for detrital zircon U-Pb age dating to constrain the provenance supported by sandstone petrography. This combined approach will provide an insight into the Himalayan exhumation in western Himalaya.

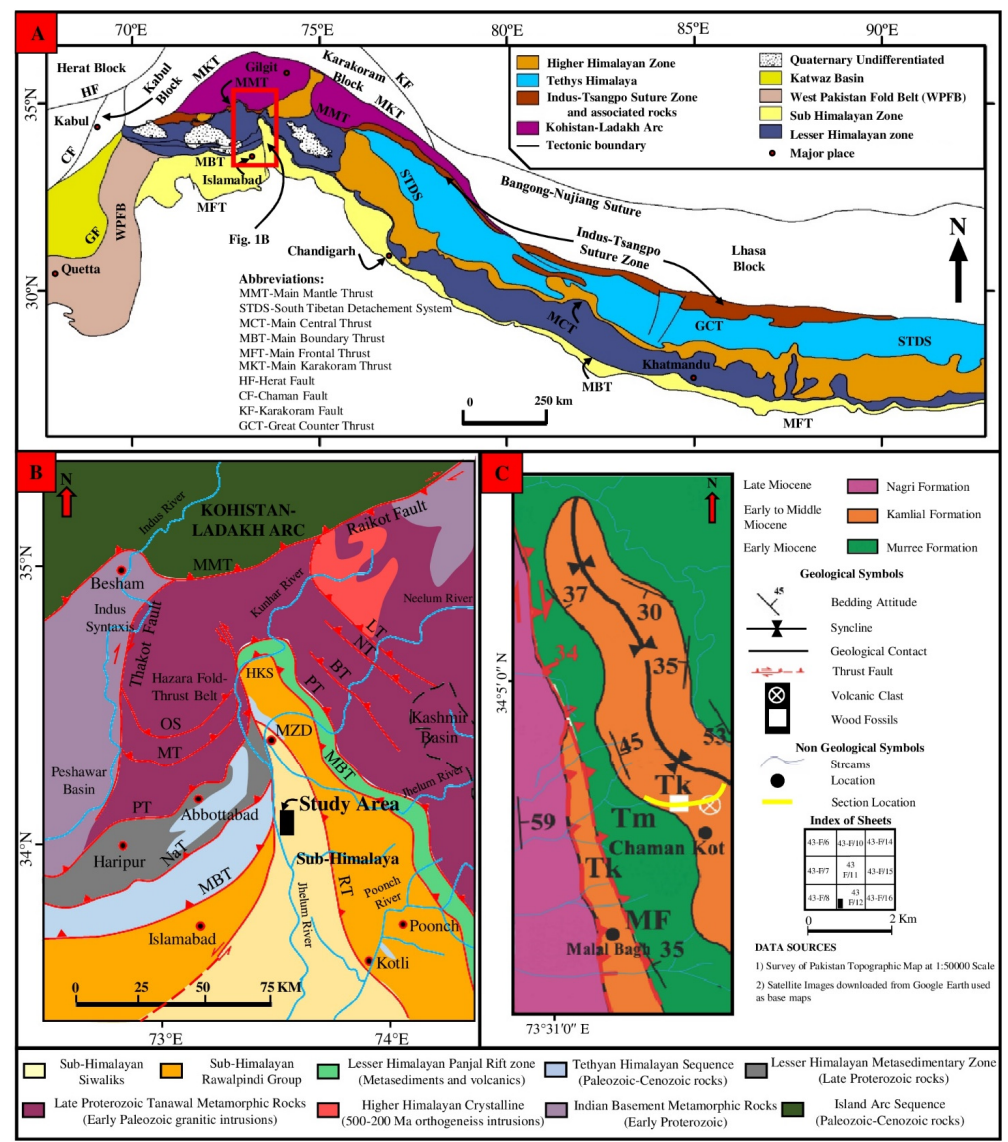

Figure 1. (A) Simplified tectonic map showing major boundary faults and related tectonostratigraphic 
zones (taken from Awais, et al. [4] and based on many sources referenced therein). The red rectangle shows the extent of Figure (B). (B) Geological map of Hazara-Kashmir syntaxis and adjacent areas (after Baig and Lawrence [22]). A filled black rectangle represents the study area. MMT-Main Mantle Thrust, LT-Laut Thrust, NT-Neelum Thrust, BT—Barian Thrust, PT—Panjal Thrust, HKS-Hazara Kashmir Syntaxis, MBT-Main Boundary Thrust, MZD—Muzaffarabad, OS—Oghi Shear zone, MTMansehra Thrust, NaT—Nathia Gali Thrust and RT-Riasi Thrust. (C) Simplified geological map of the study area (adopted after Razzaq [27]) showing the location of the studied stratigraphic section.

\section{Regional Geology}

The Himalaya appeared on the earth's crust in response to the continent-continent collision of Indian and Asian plates in the Cenozoic [1]. The interaction of these plates occurred in response to the closure of the intervening ocean basin along the Indus suture zone/Main Mantle Thrust (MMT). As a result, a foreland basin was developed on the northern Indian margin in the footwall of MMT [28]. This basin received the detritus from the Asian plate and the Indian plate in response to the evolution of the mountain system. The Kohistan-Ladakh arc (KLA) is a magmatic arc representing the southern margin of the Asian plate, which is accreted to the Karakoram block along MKT. The Early Cretaceous to Paleocene igneous rocks belonging to KLA represent a typical island arc sequence [29]. The northern and western part of the KLA consist of Late CretaceousPaleocene volcanic and sedimentary rocks [30]. The Early Cretaceous (110-85 Ma) age Kohistan batholith is cropped out in the central part of the arc [31]. The Kohistan batholith is intruded by younger $\approx 34-29$ Ma leucogranitic sills and dikes [32]. The southern part of the arc is comprised of ultramafic-mafic plutonic complexes named as Jijal complex, Spat complex, and Chilas complex of Middle Cretaceous (120-80 Ma) age [33-35], which intruded into a pre- early-arc metavolcanic basement complex called Kamila amphibolites of Early Cretaceous age [29,36]. The southern part of the KLA is obducted onto the northern Indian margin along the MMT and marks the collision zone between the Indian Plate and Kohistan-Karakoram terrane [37].

Immediate to the south of the collision zone (MMT), Indian Plate rocks can be described by dividing them into three tectonostratigraphic zones, which are from north to south as (1) internal metamorphosed zone, (2) external low-grade metamorphic zone, and (3) foreland basin sediments [38]. The internal metamorphosed zone comprises an intensely deformed imbricate stack of middle Proterozoic to Archean metamorphic rocks, which are dominantly high-grade gneisses and pelitic schists intruded by Cambrian-Ordovician granitic intrusions [39]. The internal zone is dominantly characterized by Barrovian-type high-grade metamorphism, but locally, high-pressure metamorphism is represented by eclogite such as those reported from the upper Kaghan valley [40]. The Panjal Thrust separates the internal metamorphosed zone from the external low-grade metamorphic zone. This external zone consists of weakly metamorphosed late Proterozoic rocks and Mesozoic to Eocene sedimentary deposits.

Further to the south, the MBT marks the boundary between the external zone and the foreland basin sequence. It consists of Paleocene-Eocene marine sediments, overlain by Oligocene-Miocene and younger siliciclastic strata marking regional unconformity [41,42]. In terms of the Himalayan classification [43], part of the internal metamorphosed zone, north of MCT (Laut Thrust/Batal Fault), marks the Greater/Higher Himalaya (Figure 1A,B). The Lesser Himalayan zone is marked between the MBT and MCT (Laut Thrust/Batal Fault). The Hazara-Kashmir syntaxial region in Pakistan represents the foreland basin's northern extreme, currently occupying the sub-Himalayan region [8]. It contains marine sediments (Paleocene-Eocene) overlain by molasse sediments (Oligocene-younger) [44] The Kamlial Formation lies toward the top of the stratigraphy of the molasse sequence in the Sub Himalaya [7] and is positioned stratigraphically below the Siwaliks, around $35 \mathrm{~km}$ to the southeast of the Muzaffarabad (Figure 1B).

The Kamlial Formation is widespread in the sub-Himalaya in Pakistan with variable thickness, ranging from 100 to $\approx 580 \mathrm{~m}$ [25]. The Kohala section represents its northernmost 
exposure within the sub-Himalaya. The thickness of the Kamlial Formation in this section is $\approx 102 \mathrm{~m}$ (Figure $2 \mathrm{~A}$ ) and exposed in a synclinal structure (Figures $1 \mathrm{C}$ and $2 \mathrm{~B}$ ). The dominant component of the formation is greenish-gray sandstone, which is $\approx 74 \%$ and portrays spheroidal weathering. The sandstone is medium to coarse-grained and well compacted. It also consists of wood (Figure 2C) and leaf imprint fossils. The second major portion of the formation consisted of maroon siltstone and mudstone (Figure 2D), which is $\approx 20 \%$ of the total thickness. The rest of the formation consisted of intraformational conglomerates and paleosol layers (Figure 2E,F). The bioturbation is also observed in the sandstone (Figure 2G). In addition, volcanic clast (Figure $2 \mathrm{H}$ ) is also observed in the sandstone, possibly associated with the Panjal volcanics. It is also observed that the lower portion of the Kamlial Formation is dominated in siltstone and mudstone, while the upper part is dominated in sandstone (Figure 2B). The Kamlial Formation consisted of a cyclic deposition of mudstone, siltstone, and sandstone in a fining upward sequence. This cyclic sequence and sedimentary structures represent the deposition by braided streams.

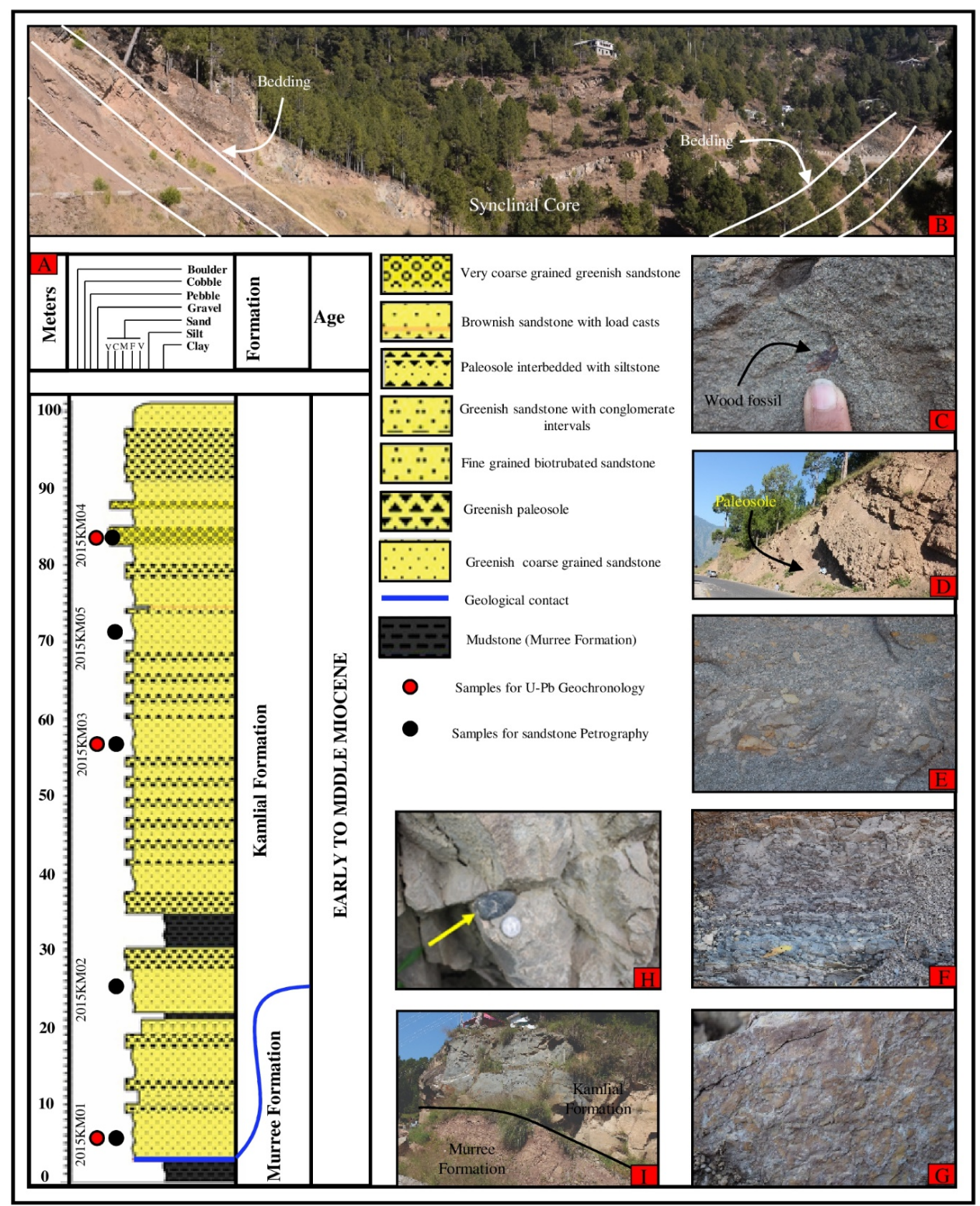

Figure 2. (A) Measured stratigraphic section of the Kamlial Formation showing lithological variation 
near Chamankot along Kohala-Bagh road, Azad Kashmir, Pakistan. (B) Panoramic overview of the outcrop of the Kamlial Formation in a Chamankot synclinal core. (C) Coarse-grained greenish sandstone of the Kamlial formation showing wood fossils. (D) Brownish color sandstone with paleosol layers in the lower part. (E) Sandstone with the intraformational conglomerate. (F) Green color paleosol layer observed in the Kamlial Formation. (G) Bioturbated sandstone of the Kamlial Formation. (H) Volcanic clast in the sandstone of Kamlial Formation. (I) Photograph showing the lower contact between Murree Formation and Kamlial Formation.

The Kamlial Formation has transitional contact with the underlying Murree Formation (Figure 2I), while the upper contact is not exposed in the study area. However, in the vicinity of the studied area, it is conformable with the overlying Chinji Formation of the Siwalik group.

\section{Analytical Methods}

\subsection{Petrography}

The traditional petrography is widely applied to determine the composition of the sandstones and their provenance $[45,46]$. The sandstone petrography was used to supplement the detrital zircon $\mathrm{U}-\mathrm{Pb}$ age data in this study. A total of five sandstone samples from the entire section were selected for sandstone petrography. Thin sections of the samples were prepared in the Rock Cutting and Thin section lab at the Department of Earth Sciences, COMSATS University Islamabad, Abbottabad Campus, Pakistan.

Each thin section was examined under a polarized petrographic microscope, and $>300$ framework grains (Quartz, feldspars and lithics) were counted from the different views of the thin section following the Gazzi-Dickinson point-counting method [46].

\subsection{Zircon Imaging}

The detrital zircons extracted from the selected studied samples represent the multiple sources from the different blocks, consisting of sedimentary, metamorphic, and igneous rocks. It is important to image the detrital zircons before the in situ U-Pb analysis [47,48]. The cathode luminescence (CL) images were recorded for all three samples, which clearly show the internal structure of the detrital zircons (Supplementary Figure S1). The analysis spots are placed at the outer part in zircons, which reflects a complex rim to core internal structure (Supplementary Figure S1).

\subsection{U-Pb Detrital Zircon Dating}

$\mathrm{U}-\mathrm{Pb}$ dating of the detrital zircon is a modern technique extensively used in clastic sediments and provides significant information about the sediment source region by comparing ages with the ages of the adjacent source terranes. In this study, the samples of the Kamlial Formation were selected for detrital zircon $\mathrm{U}-\mathrm{Pb}$ dating to constrain the provenance. A total of three samples were collected representing the bottom, mid, and upper part of the formation from the southwestern limb of Chamankot syncline (Figures 1C and 2A).

The detrital zircon grains were isolated using heavy liquids and the magnetic separation method from the crushed sandstone samples. In a second stage, these isolated zircon grains were mounted on a glue strip, and then, the epoxy resin was poured on the strip to prepare the sample for polishing. Finally, the prepared samples were polished to make the surface of the grains smooth.

In the analysis stage, to avoid lead contamination, the mounted detrital grains' surface was cleaned with dilute nitric acid and pure alcohol before $\mathrm{U}-\mathrm{Pb}$ analysis. The U-Pb age dating was conducted at the Key Laboratory of Continental Collision and Plateau Uplift, Institute of Tibetan Plateau Research, Chinese Academy of Sciences, Beijing, China. From each sample, 100 individual detrital grains were analyzed using an Agilent 7500a Laser Ablation Inductively Plasma Mass Spectrometer (LAICPMS). Each analyzed spot has a diameter of $35 \mu \mathrm{m}$. The ages of the unknown detrital grains were calibrated using the Plesovice standard (average age of $337+0.37 \mathrm{Ma}$ ) [49]. The final ages of the detrital grains 
were selected using two age systems. The ${ }^{207} \mathrm{~Pb} /{ }^{206} \mathrm{~Pb}$ age system was adopted for the detrital zircon grains with ages $>1400 \mathrm{Ma}$, whereas the ${ }^{206} \mathrm{~Pb} /{ }^{238} \mathrm{U}$ age system was adopted for the zircon grain with ages $<1400 \mathrm{Ma}$ [50]. The grains with $>10 \%$ discordance in each age system were excluded in the final data interpretation. The raw data were processed using Glitter 4.0 software. The age data were displayed in probability density plots using Isoplot [51] and provided in Table S1.

\section{Results}

\subsection{Petrography}

Five thin sections were prepared from the collected samples covering the entire measured section. The samples 2015KM01 and 2015KM02 represented the lower part and were collected from the medium to coarse-grained greenish color thickly bedded sandstone (Figure 2A). The samples 2015KM03 and 2015KM05 represented the middle part and were collected from the greenish-gray sandstone. Similarly, the sample 2015KM04 represented the upper portion of the Kamlial Formation and was collected from the very coarse-grained greenish sandstone (Figure 2A).

The grains of samples are sub-rounded to angular, with calcite and siltstone cementing materials. The framework grains consisted of quartz, feldspar, and lithics (Figure 3A). The monocrystalline quartz is abundant (Figure 3B,G). However, few polycrystalline quartz grains were observed in all thin sections (Figure 3C). The feldspar includes both the Kfeldspar and Na-feldspar. The albite is prominent in the thin section (Figure 3B,G). The lithics consisted of all three rocks (Figure 3B-E). Igneous and metamorphic lithics are very common (Figure 3B,E,G). The sedimentary lithics were mostly the shales and siltstone (Figure 3C,D). However, few sedimentary carbonate lithics were also observed in the thin section (Figure 3F,G). In addition, mica was also observed in the thin sections, including biotite and muscovite (Figure 3D,G).

\begin{tabular}{|l|ccc|c|}
\hline $\mathbf{A}$ & \multicolumn{3}{|c|}{ QtFLt (\%) } & \multirow{2}{*}{ Formation Name } \\
\cline { 2 - 4 } Sample \# & Qt (\%) & F (\%) & Lt (\%) & \\
\hline 2015KM01 & 75 & 5 & 20 & \\
\hline $2015 \mathrm{KM} 02$ & 67 & 4 & 29 & \multirow{2}{*}{ Kamlial Formation } \\
\hline 2015KM03 & 63.21 & 5.68 & 31.11 & \\
\hline 2015KM04 & 55.19 & 6.92 & 37.89 & \\
\hline 2015KM05 & 52.86 & 5.72 & 41.42 & \\
\hline
\end{tabular}
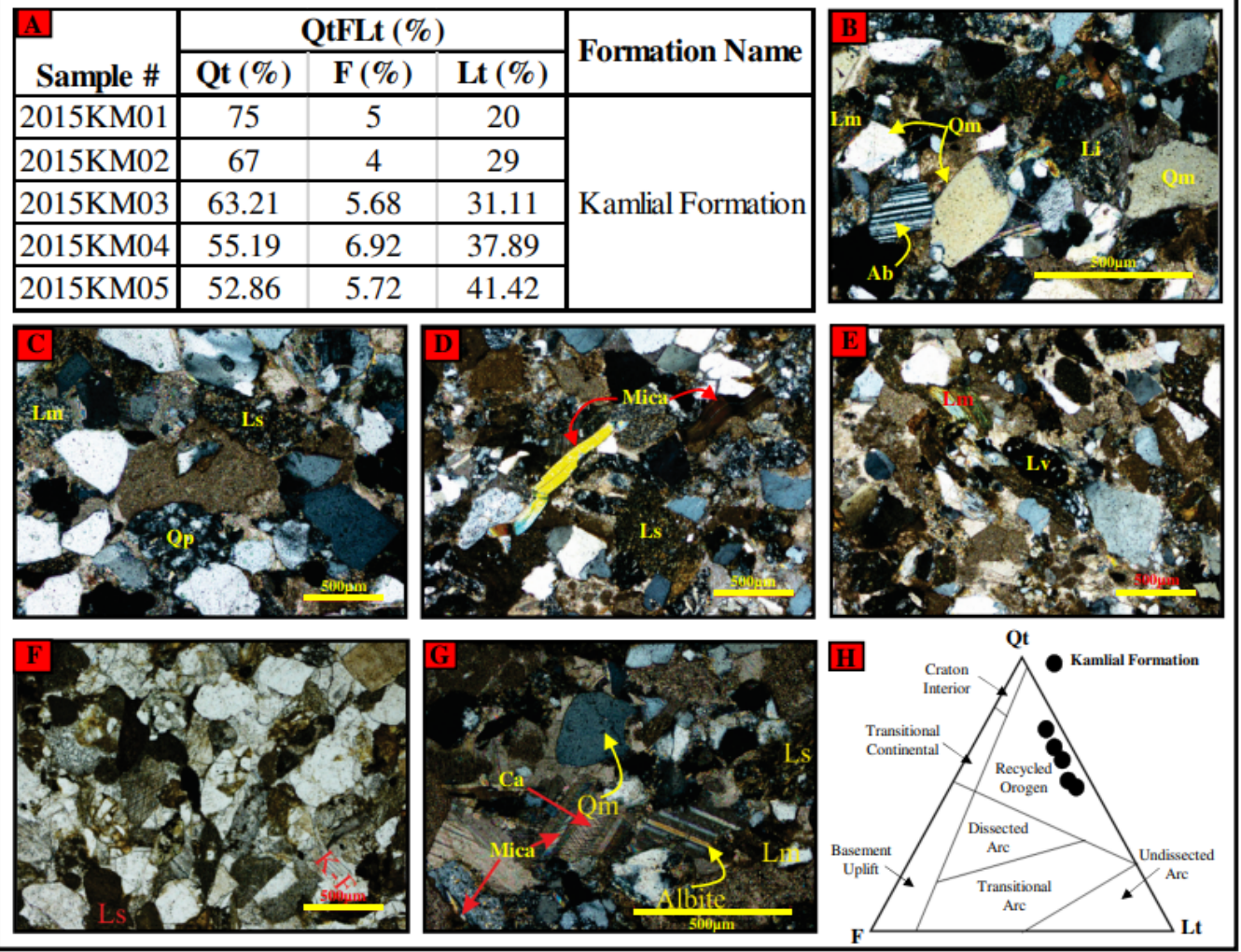

Figure 3. (A) Percentage composition of the framework grains of the studied sandstone thin sections 
of the Kamlial Formation. (B-G) Photomicrographs of sandstone samples of the Kamlial Formation showing quartz (monocrystalline and polycrystalline), feldspar (K-feldspar and Na-feldspar), various lithics including igneous ( $\mathrm{Li}$ and Lv), sedimentary (Ls), and metamorphic (Lm), and mica. Ca represents carbonate lithic. $(\mathbf{H})$ Tectonic discrimination plot showing recycled orogenic provenance for the samples of Kamlial Formation [46].

The percentage composition of the framework grains calculated through the pointcounting method suggests that the quartz concentration ranges between $\approx 52$ and $75 \%$, the feldspar concentration ranges between 4 and $6.92 \%$, and the lithics concentration ranges between 20 and 41.42\% (Figure 3A). The data plotted on the QtFLt diagram of the Dickinson [46] placed the samples of the Kamlial Formation within the recycled orogen provenance (Figure $3 \mathrm{H})$.

\subsection{Zircon Geochronology}

\subsubsection{Detrital Zircon U-Pb Dating Results}

Detrital zircon geochronology has been the most accurate and reliable method for determining the provenance of sediments for the last few decades because detrital zircon is chemically stable and mechanically robust in various depositional environments and weathering conditions. According to previous provenance studies based on $\mathrm{U}-\mathrm{Pb}$ detrital zircon dating, the recommended number of selected zircon grains is 80-100 grains per sample to precisely determine the source components of the sediments [52]. In this research, we adopted $\mathrm{U}-\mathrm{Pb}$ age dating of the detrital zircons, extracted from sandstones of the Kamlial Formation exposed along Kohala-Bagh road section, sub-Himalaya, Azad Kashmir, Pakistan, for constraining the provenance. The results of the analyzed samples are described below in detail.

Sample 2015KM01 was collected above the lower contact of the Kamlial Formation with Murree Formation from a coarse sandstone horizon (Figure 2A). One hundred detrital zircons were analyzed for U-Pb age dating. One hundred analyses yielded 98 concordant ages (Figure 4, Table S1). The highest concentration of detrital zircons occurred between $\approx 400$ and $\approx 1000 \mathrm{Ma}$, with peak ages of $\approx 432 \mathrm{Ma}, \approx 484 \mathrm{Ma}$, and $\approx 875 \mathrm{Ma}$ (Figure 4 ). There were a few subordinate peaks of Paleoproterozoic ages $(\approx 1600-2500 \mathrm{Ma})$ and Mesoproterozoic ages $(\approx 1000-1600 \mathrm{Ma})$ age. In addition, a younger age cluster existed between $\approx 31$ and $\approx 134 \mathrm{Ma}$, with peak ages at $\approx 72 \mathrm{Ma}$ and $\approx 93 \mathrm{Ma}$ (Figure 4 ).

The sample 2015KM03 represents the middle part of the formation. All the 100 detrital zircons yielded concordant ages. The major proportion of the detrital zircon ages existed between $\approx 453$ and $\approx 1150 \mathrm{Ma}$, which is $\approx 70 \%$ of the total proportion (Figure 4 ). The age peaks were recorded in this broad range at $\approx 495 \mathrm{Ma}, \approx 525 \mathrm{Ma}, \approx 615 \mathrm{Ma}$, and $\approx 978 \mathrm{Ma}$ (Figure 4 ). The second cluster existed between $\approx 1500$ and $\approx 2000 \mathrm{Ma}$, which is $\approx 10 \%$ of the total proportion. The rest of the detrital ages were scattered between $\approx 2100$ and $\approx 3300$ Ma (Figure 4). Only two younger detrital ages were reported from the 2015KM03 sample, which were $95 \mathrm{Ma}$ and $118 \mathrm{Ma}$.

The sample 2015KM04 represents the upper portion of the Kamlial Formation. Out of 100 analyses, 96 detrital zircons yielded concordant ages (Figure 4, Table S1). The probability density plot shows that the major cluster existed between $\approx 500$ and $\approx 680 \mathrm{Ma}$ $(\approx 23 \%), \approx 700$ and $\approx 1120 \mathrm{Ma}(\approx 40 \%)$ and $\approx 1200$ and $\approx 1830 \mathrm{Ma}(\approx 24 \%)$ (Figure 4$)$. In addition, a minor age cluster existed between $\approx 2200$ and $\approx 2470 \mathrm{Ma}$, which is $\approx 6 \%$ of the total proportion (Figure 4 ). The major age peaks were recorded at $\approx 550 \mathrm{Ma}, \approx 650 \mathrm{Ma}$, $\approx 765 \mathrm{Ma}, \approx 800 \mathrm{Ma}$, and $\approx 965 \mathrm{Ma}$ (Figure 4 ). The youngest ages reported in this sample were $86 \mathrm{Ma}, 94 \mathrm{Ma}$, and $112 \mathrm{Ma}$ (Figure 4). 


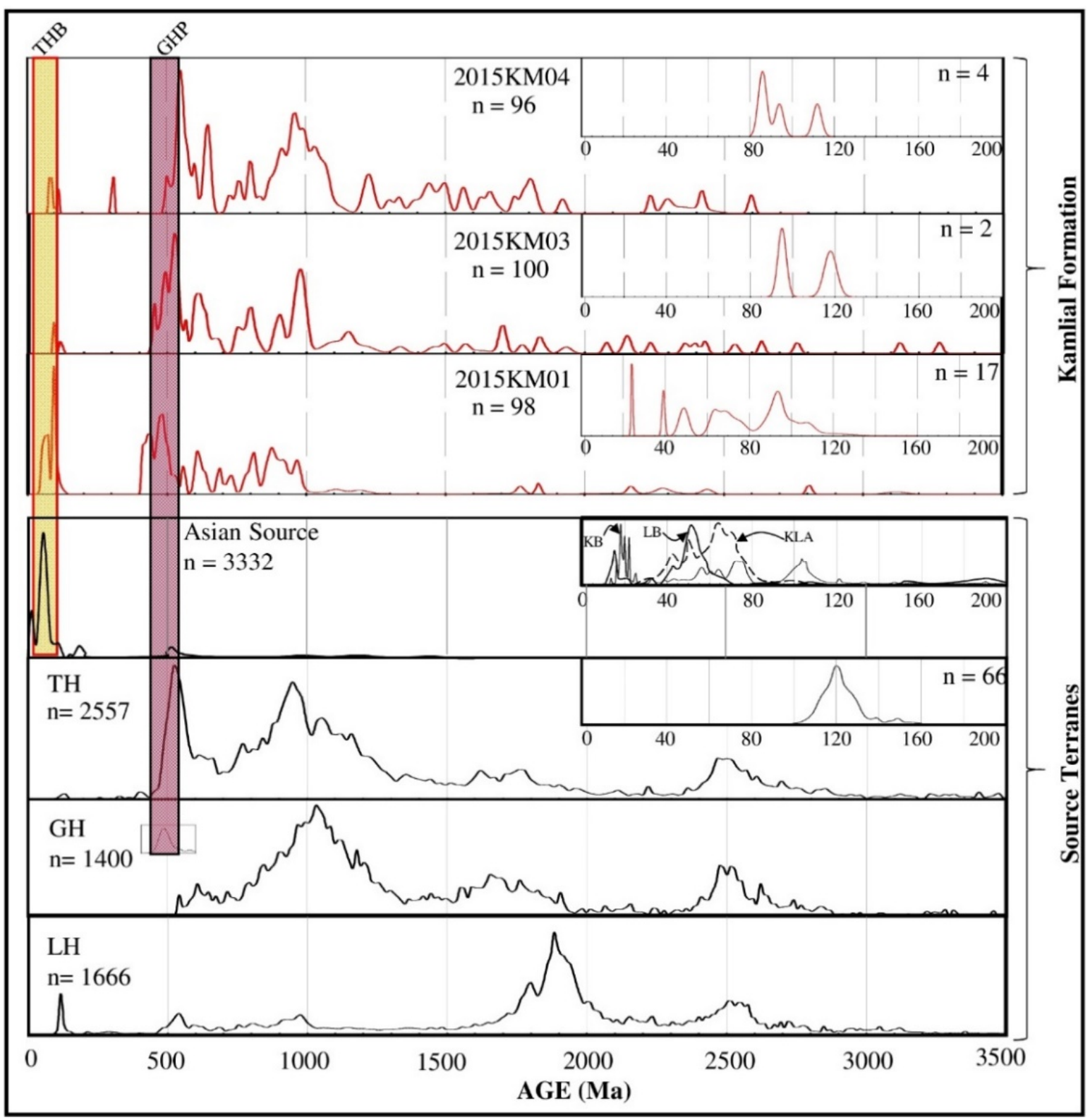

Figure 4. $\mathrm{U}-\mathrm{Pb}$ probability density plots of the studied samples of the Kamlial Formation and the source terranes [53] where LH, GH, TH, KLA, LB, KB, THB, and GHP stand for Lesser Himalaya, Greater Himalaya, Tethyan Himalaya, Kohistan-Ladakh Arc, Lahasa Block, Karakoram Block, TransHimalayan batholiths, and Greater Himalayan Pluton, respectively.

\subsubsection{Internal Zoning Pattern and Th/U ratio}

The CL images of the detrital zircons show different internal zoning patterns [47], which indicates the derivation from different sources, including igneous, metamorphic, and sedimentary rocks $[54,55]$. The size of the zircon grains ranges from 50 to $>200 \mu \mathrm{m}$ (Supplementary Figure S1). The analyzed zircons abundantly displayed the oscillatory zoning pattern, indicating the igneous origin's derivation. In addition, the zircons with xenocrystic cores are also present [47]. A fair number of the detrital zircons displayed the metamorphic textures with a well-developed core and younger rims (Supplementary Figure S1). However, a sufficient number of zircons also display plane texture without any zonation. Some analyzed zircons possessed sector zoning patterns (Supplementary Figure S1).

In addition, the zircon $\mathrm{Th} / \mathrm{U}$ ratio is also an important elemental ratio, which is used to discriminate between the metamorphic and igneous origin zircon [56,57]. The detrital zircon 
grains derived from the igneous origin possessed a Th/U ratio value $>0.3$, whereas the detrital zircons with a Th/U ratio $<0.3$ indicate the metamorphic origin [57]. The U-Pb ages of the detrital zircons and Th/U ratio plot reflect the detrital zircons' dominant population from the igneous origin (Figure 5). However, a significant population between $\approx 400$ and $\approx 1200$ Ma reflects the metamorphic origin. This metamorphic episode is most possibly associated with the Pan-African orogeny, which is well documented in the northwestern Himalayas [58]. At the same time, the igneous zircons in this similar age domain might represent the lesser Himalayan granites, which possessed similar ages $[59,60]$. The younger population of detrital ages < 100 Ma reflects the igneous origin dominantly (Figure 5). In contrast, the younger grains reflect the metamorphic origin, which is more likely associated with Himalayan metamorphism $[61,62]$.

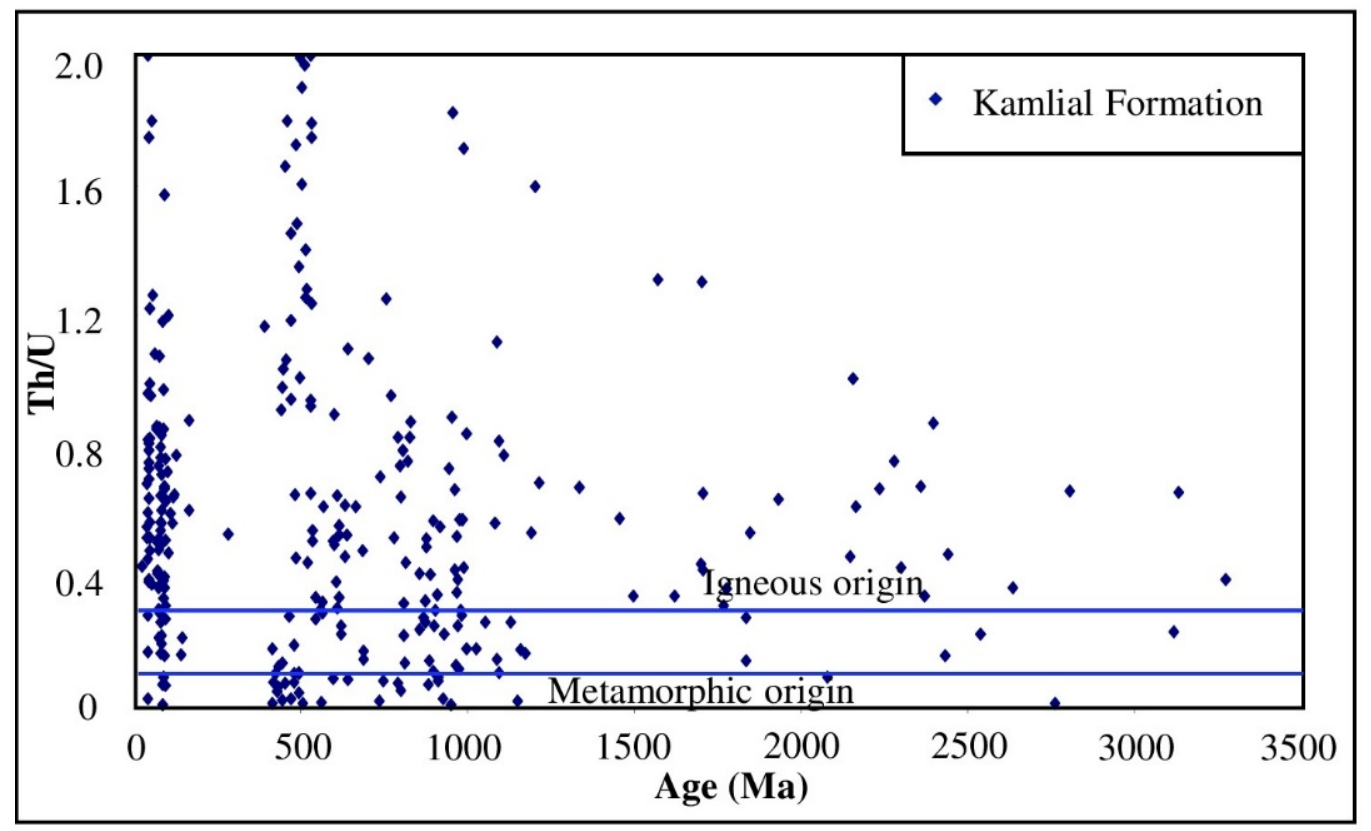

Figure 5. Binary plot showing $\mathrm{Th} / \mathrm{U}$ ratio vs $\mathrm{U}-\mathrm{Pb}$ ages reflecting the igneous and metamorphic origin zircons.

\section{Discussion}

\subsection{Provenance Interpretation}

\subsubsection{U-Pb Ages of Source Terranes}

The interpretation of the detrital zircon provenance for the middle to late Miocene Kamlial Formation, exposed along the Kohala-Bagh road section, requires the representative $\mathrm{U}-\mathrm{Pb}$ age dataset for the adjacent litho-tectonic terranes, which were possible contributing sediment sources during Himalayan mountain evolution. These litho-tectonic terranes include Himalayan tectonostratigraphic zones (Tethyan Himalaya, Higher/Greater Himalaya (GH), and Lesser Himalaya (LH)) and Asian sources (Kohistan-Ladakh arc (KLA), Karakoram Block (KB), and Lahasa Block (LB)) (Figure 4) [53]. These terranes have distinct age spectra, which discriminate them from one another. The Asian sources were grouped for simplicity, as these terranes were already accreted to the Indian plate following the final collision [7].

The Asian terranes possessed a distinct age pattern, with a majority of the zircon ages clustered between $\approx 20$ and $\approx 120$ Ma (Figure 4 ). These ages were representative of the younger batholiths associated with the magmatism during the collision process. The presence of these younger ages in the evolving basins indicates these terranes' contribution. The Himalayan tectonostratigraphic zones are important in understanding the evolution of the mountain belt. These tectonostratigraphic zones possessed a unique age pattern representing the specific block's sources. The zircons from the LH typically yielded age clus- 
ters around 1700-1900 Ma with subordinate minor age clusters around 2400-2600 Ma [53]. The detrital zircons from the GH sequence displayed age clusters around 540-750 Ma, 800-1200 Ma, 1600-1900 Ma, and 2400-2600 Ma (Figure 4). The dominant ages of the GH sequence clustered around 900-1100 Ma $[28,53,63]$. The detrital zircon record of the intruding granitic body depicted age clusters between 470 and 550 Ma with a prominent peak at $485 \mathrm{Ma}$ [64]. The TH detrital age spectra are similar to the GH sequence. However, the 480-570 Ma age cluster is more distinct than other clusters such as 700-1200 Ma and 2430-2560 Ma (Figure 4) $[65,66]$. The Tethyan strata also contain younger detrital zircon grains ranging between 110 and $140 \mathrm{Ma}$, which are representative of Indian Plate volcanic rocks $[15,16,28,53]$.

\subsubsection{Provenance of Kamlial Formation}

The detrital zircon U-Pb plots of the studied samples of Kamlial Formation portrayed the age pattern mainly clustered around $\approx 400-1200$ Ma with major peaks at $\approx 550 \mathrm{Ma}$, $\approx 650 \mathrm{Ma}, \approx 800 \mathrm{Ma}$, and $\approx 978 \mathrm{Ma}$ (Figure 3). In addition to this prominent component, a significant age pattern existed between $\approx 1600$ and $\approx 1900 \mathrm{Ma}$. This age component is more distinct in the samples representing middle and upper parts (Figure 4). In comparison, minor scattered ages existed between $\approx 2000$ and $\approx 3000 \mathrm{Ma}$. The younger detrital zircon ages reported in the samples were low in percentage $(\approx 8 \%)$. However, these younger ages suggested the Asian provenance contribution. The Th/U ratio of the younger grains are mostly higher than 0.3 , which supports the igneous origin. However, few younger grains with Th/U ratio lower than 0.3 reflect Himalayan metamorphism's imprints.

The major age cluster $(\approx 400-1200 \mathrm{Ma})$ resembled the Tethyan and Greater Himalayan sequences (Figure 4). It suggests that the major contributing tectonostratigraphic zones during the deposition of the Kamlial Formation were Tethyan and Greater Himalayas. However, the increased input of the detritus portraying the ages between $\approx 1600$ and $\approx 1900$ Ma reflected the contribution of the Lesser Himalayan tectonostratigraphic zone. This pattern is comparatively more pronounced in the samples representing the middle and upper portions of the formation. Considering the contribution from the Himalayan sources and Asian sources, it is suggested that the Kamlial Formation received the mixed detritus indicative of the sediment recycling and southward propagation of the fold-thrust belt. The sandstone petrography also supports the sediment recycling reflected by "Recycled orogen" provenance (Figure $3 \mathrm{H}$ ). This sediment recycling also supports the uplifting of the blocks and erosion and depositing in a new site.

\subsection{Tectonic Implications for Himalayan Exhumation}

The Himalayas resulted from the India-Asia collision that occurred $\approx 56 \mathrm{Ma}[1,4,7]$. Following the collision, a foreland basin was developed in the footwall of the MMT, which received detritus from the accreted Asian terranes, mainly the Kohistan-Ladakh arc (Figure 6A). As a result of the continued subduction of the Indian plate in the north underneath, the Asian plate gave rise to Himalayan belt evolution by southward propagation of the fold-thrust belt.

In the first developed foreland basin, the shallow marine carbonate sequence was formed in Margalla Hill Limestone and Chorgali formations [7]. The shallow marine conditions prevailed during the foreland basin's initial development, such as the case of the Australia and Papua New Guinea collision [67]. With the emergence of Batal Fault/MCT, the foreland basin moved to the footwall of the Batal fault/MCT and started to receive recycled detritus from the Greater/Higher Himalayan block together with Asian sources and resultantly deposition of the Kuldana and Murree formations occurred during 43-35 Ma (Figure 6B) [1]. 


\section{ca. 55-50 Ma}

Final India-Asia collision and Palecoene-Eocene Sequence deposition

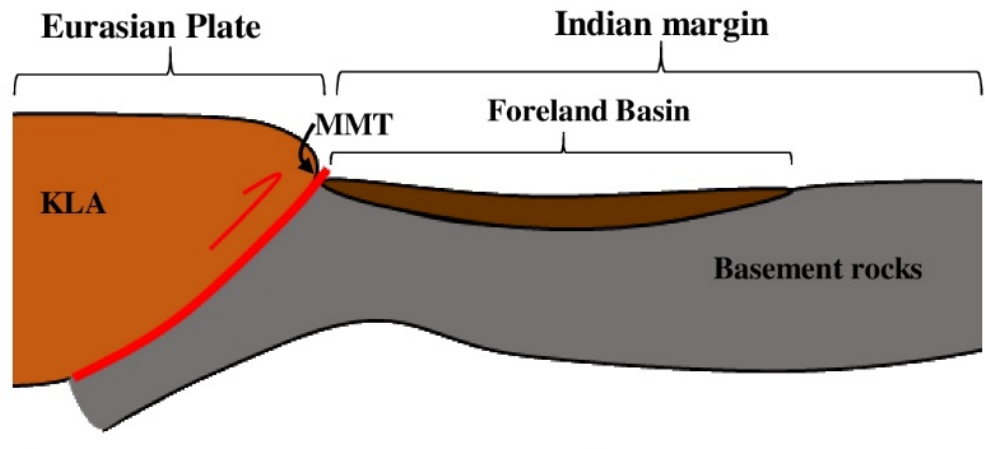

ca. 45-35 Ma

Activation of MCT and uplifting of Higher Himalayan block

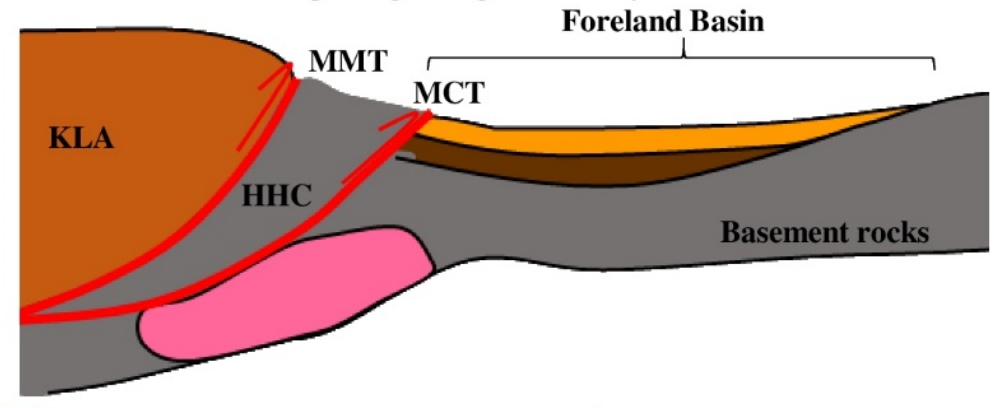

ca. 25-15 Ma

Activation of PT and uplifting of Lesser Himalayan block

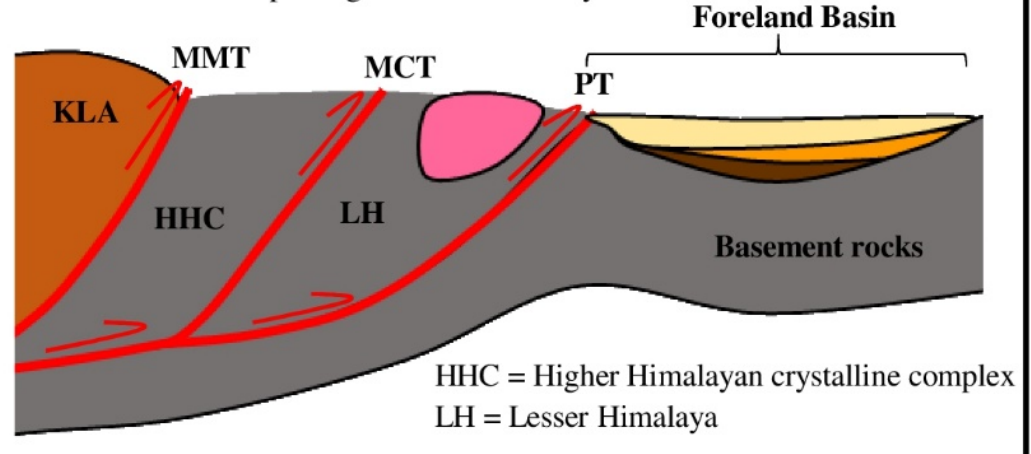

Kohistan-Ladakh arc (KLA)

Paleozoic granitoids

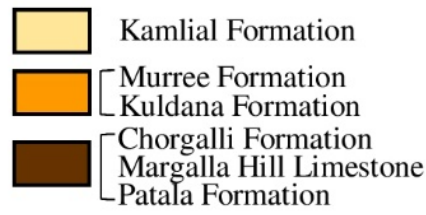

Figure 6. Tectonic model (not to scale) explaining the provenance and exhumation of the Himalayan block. (A) An impression of the first foreland basin in response to the India-Asia collision in northwestern (NW) Himalaya, Pakistan (modified after Ding, Qasim, Jadoon, Khan, Xu, Cai, Wang, Baral, and Yue [1] and Mughal, Zhang, Du, Zhang, Mustafa, Hameed, Khan, Zaheer, and Blaise [26]). (B) Shifting of the foreland basin in response to fold-thrust belt propagation and emergence of MCT. (C) It shows the exhumation of the Lesser Himalayan block in response to the emergence of Panjal Fault and resultantly, the foreland basin depocenter shifted to the footwall of the Panjal fault and deposition of the Kamlial Formation occurred (this study). 
Relying on the U-Pb age data and sandstone petrography of the Kamlial Formation suggests that the provenance is from the Himalayan sources, including Tethys Himalaya, Greater/Higher Himalaya, and Lesser Himalaya. These Himalayan tectonic terranes consisted of particular detrital zircon age signatures. These terranes uplifted with the development of new faults in response to fold-thrust belt propagation. Particularly, the $\mathrm{U}-\mathrm{Pb}$ ages compared with the $\mathrm{Th} / \mathrm{U}$ ratio indicates the derivation from the igneous and metamorphic sources of the Proterozoic and Cambro-Ordovician rocks. These Proterozoic and Cambro-Ordovician age metamorphic rocks are widely exposed in the Higher Himalayan crystalline and Lesser Himalayan sequences. The U-Pb ages together with the Th/U ratio suggest the source of the Kamlial Formation from the rocks exposed in Tethyan, Greater/Higher, and Lesser Himalaya. This mixed source suggests that the foreland basin during the middle to late Miocene time existed in the footwall of the Panjal fault that received the source from the Lesser Himalayan block (Figure 6C). Considering the age of the Kamlial Formation, it can be deduced that the Panjal fault activated during 25-14 Ma. The felsic lithics and increased Cambrian-Ordovician ages in the detrital record suggest the exhumation of the Mansehra granite, which is mainly exposed in the hanging wall of the Panjal fault.

\section{Conclusions}

This study presented first-time detrital zircon U-Pb geochronology supported with sandstone petrography of the middle to late Miocene Kamlial Formation to constrain the provenance and its implications for Himalayan Exhumation in the western Himalayas, Pakistan. Our results suggest that the sediments of the Kamlial Formation were mainly sourced from the Himalayan tectonostratigraphic zones, including Tethyan, Greater and lesser Himalaya, with a contribution from the Asian sources as reflected by younger ages $(<150 \mathrm{Ma})$. It is worth mentioning that the Lesser Himalayan contribution $(\approx 1600-1900 \mathrm{Ma})$ is more pronounced in the middle and upper part of the formation, as reflected in samples 2015KM03 and 2015KM04. Considering this provenance, we proposed a tectonic model that explains the exhumation of the Himalayan tectonostratigraphic zones. This model suggests that the Tethyan and Greater Himalayan tectonostratigraphic zones were already uplifted during the Eocene to Early Miocene time and feeding the foreland basin in the footwall of MCT. However, during the deposition of the Kamlial Formation, the Lesser Himalayan tectonostratigraphic zone uplifted in response to the activation of the Panjal Fault at least around $\approx 24-14 \mathrm{Ma}$. With this exhumation, the contribution from the Lesser Himalayan block started and was reflected in the sediments of the Kamlial Formation.

Supplementary Materials: The following are available online at https:/ / www.mdpi.com/article/10 $.3390 / \min 12030298 / \mathrm{s} 1$, Table S1. U-Pb age dating data of the studied samples of Kamlial Formation, Kasmir basin, Pakistan. Figure S1: CL images of the studied samples of the Kamlial Formation, Kashmir, Northwestern Himalaya, Pakistan.

Author Contributions: Funding acquisition, L.D.; investigation, L.A.; supervision, M.Q. and J.I.T.; writing—original draft, M.Q.; writing—review and editing, Q.U.R. and U.U. All authors have read and agreed to the published version of the manuscript.

Funding: This study was financially supported by grants from National Natural Science Foundation of China (41490610), the Chinese Ministry of Science and Technology (2011CB403101), and the International partnership program of the Chinese Academy of Sciences (131551KYSB20200021).

Data Availability Statement: Data is available in the Table S1.

Acknowledgments: This study is part of the thesis produced at the Department of Earth Sciences, COMSATS University Islamabad, Abbottabad Campus, Pakistan and PIFI research.

Conflicts of Interest: Authors have no conflict of interest. 


\section{References}

1. Ding, L.; Qasim, M.; Jadoon, I.A.K.; Khan, M.A.; Xu, Q.; Cai, F.; Wang, H.; Baral, U.; Yue, Y. The India-Asia collision in north Pakistan: Insight from the U-Pb detrital zircon provenance of Cenozoic foreland basin. Earth Planet. Sci. Lett. 2016, 455, 49-61. [CrossRef]

2. $\quad$ DeCelles, P.G.; Giles, K.A. Foreland basin systems. Basin Res. 1996, 8, 105-123. [CrossRef]

3. Najman, Y. The detrital record of orogenesis: A review of approaches and techniques used in the Himalayan sedimentary basins. Earth-Sci. Rev. 2006, 74, 1-72. [CrossRef]

4. Awais, M.; Qasim, M.; Tanoli, J.I.; Ding, L.; Sattar, M.; Baig, M.S.; Pervaiz, S. Detrital Zircon Provenance of the Cenozoic Sequence, Kotli, Northwestern Himalaya, Pakistan; Implications for India-Asia Collision. Minerals 2021, 11, 1399. [CrossRef]

5. Qasim, M.; Ahmad, J.; Ding, L.; Tanoli, J.I.; Sattar, M.; Rehman, Q.U.; Awais, M.; Umar, M.; Baral, U.; Khan, H. Integrated provenance and tectonic implications of the Cretaceous-Palaeocene clastic sequence, Changla Gali, Lesser Himalaya, Pakistan. Geol. J. 2021, 56, 4747-4759. [CrossRef]

6. Qasim, M.; Ding, L.; Khan, M.A.; Baral, U.; Jadoon, I.A.K.; Umar, M.; Imran, M. Provenance of the Hangu Formation, Lesser Himalaya, Pakistan: Insight from the detrital zircon U-Pb dating and spinel geochemistry. Palaeoworld 2020, 29, 729-743. [CrossRef]

7. Qasim, M.; Ding, L.; Khan, M.A.; Jadoon, I.A.; Haneef, M.; Baral, U.; Cai, F.; Wang, H.; Yue, Y. Tectonic implications of detrital zircon ages from lesser Himalayan Mesozoic-Cenozoic strata, Pakistan. Geochem. Geophys. Geosystems 2018, 19, 1636-1659. [CrossRef]

8. Chen, Y.; Ding, L.; Li, Z.; Laskowski, A.K.; Li, J.; Baral, U.; Qasim, M.; Yue, Y. Provenance analysis of Cretaceous peripheral foreland basin in central Tibet: Implications to precise timing on the initial Lhasa-Qiangtang collision. Tectonophysics 2020, 775, 228311. [CrossRef]

9. Dew, R.E.C.; Collins, A.S.; Morley, C.K.; King, R.C.; Evans, N.J.; Glorie, S. Coupled detrital zircon U-Pb and Hf analysis of the Sibumasu Terrane: From Gondwana to northwest Thailand. J. Asian Earth Sci. 2021, 211, 104709. [CrossRef]

10. Li, Q.; Lin, W.; Wang, Y.; Faure, M.; Meng, L.; Wang, H.; Van Nguyen, V.; Thu, H.L.T.; Lepvrier, C.; Chu, Y.; et al. Detrital zircon $\mathrm{UPb}$ age distributions and $\mathrm{Hf}$ isotopic constraints of the Ailaoshan-Song Ma Suture Zone and their paleogeographic implications for the Eastern Paleo-Tethys evolution. Earth-Sci. Rev. 2021, 221, 103789. [CrossRef]

11. Zheng, B.; Mou, C.; Wang, X.; Chen, H. U-Pb ages, trace elements and Hf isotopes of detrital zircons from the late Permian-early Triassic sedimentary succession in the northern Yangtze Block, South China: Implications for the reconstruction of the South China Block in Pangea. J. Asian Earth Sci. 2021, 206, 104609. [CrossRef]

12. Baral, U.; Lin, D.; Chamlagain, D. Detrital zircon U-Pb geochronology of the Siwalik Group of the Nepal Himalaya: Implications for provenance analysis. Int. J. Earth Sci. 2015, 105, 921-939. [CrossRef]

13. Baral, U.; Lin, D.; Chamlagain, D.; Qasim, M.; Paudayal, K.N.; Neupane, B. Detrital zircon U-Pb ages, Hf isotopic constraints, and trace element analysis of Upper Cretaceous-Neogene sedimentary units in the Western Nepal Himalaya: Implications for provenance changes and India-Asia collision. Geol. J. 2019, 54, 120-132. [CrossRef]

14. Baral, U.; Lin, D.; Goswami, T.K.; Sarma, M.; Qasim, M.; Bezbaruah, D. Detrital zircon U-Pb geochronology of a Cenozoic foreland basin in Northeast India: Implications for zircon provenance during the collision of the Indian and Asian plates. Terra Nova 2019, 31, 18-27. [CrossRef]

15. Cai, F.; Ding, L.; Yue, Y. Provenance analysis of upper Cretaceous strata in the Tethys Himalaya, southern Tibet: Implications for timing of India-Asia collision. Earth Planet. Sci. Lett. 2011, 305, 195-206. [CrossRef]

16. DeCelles, P.; Gehrels, G.; Najman, Y.; Martin, A.; Carter, A.; Garzanti, E. Detrital geochronology and geochemistry of CretaceousEarly Miocene strata of Nepal: Implications for timing and diachroneity of initial Himalayan orogenesis. Earth Planet. Sci. Lett. 2004, 227, 313-330. [CrossRef]

17. Ashraf, M.; Chaudhry, M.; Qureshi, K. Stratigraphy of Kotli area of Azad Kashmir and its correlation with standard type areas of Pakistan. Kashmir J. Geol. 1983, 1, 19-30.

18. Baig, M.S.; Munir, M.-U.-H. Foraminiferal biostratigraphy of Yadgar area, Muzaffarabad Azad Kashmir, Pakistan. J. Himal. Earth Sci. 2007, 40, 33-43.

19. Munir, M.-U.-H.; Baig, M.S. Paleogene biostratigraphy of Tattpani, Kotli Azad Kashmir, Northwest sub-Himalayas, Pakistan. J. Himal. Earth Sci. 2006, 39, 39-48.

20. Wadia, D. The syntaxis of the northwest Himalaya: Its rocks, tectonics and orogeny. Rec. Geol. Surv. India 1931, 65, 189-220.

21. Wadia, D.N. The Geology of Poonch State (Kashmir) and Adjacent Portions of the Punjab; Government of India Central Publication Branch: Calcutta, India, 1928.

22. Baig, M.; Lawrence, R. Precambrian to early Paleozoic orogenesis in the Himalaya. Kashmir J. Geol. 1987, 5, 1-22.

23. Abbasi, I.; Friend, P. Exotic conglomerates of the Neogene Siwalik succession and their implications for the tectonic and topographic evolution of the Western Himalaya. Geol. Soc. Lond. Spec. Publ. 2000, 170, 455-466. [CrossRef]

24. Abbasi, I.A.; Friend, P.F. Uplift and evolution of the Himalayan orogenic belts, as recorded in the foredeep molasse sediments. Z. Für Geomorphol. NF Suppl. 1989, 76, 75-88.

25. Kazmi, A.H.; Abbasi, I.A. Stratigraphy \& Historical Geology of Pakistan; Department \& National Centre of Excellence in Geology: Peshawar, Pakistan, 2008. 
26. Mughal, M.S.; Zhang, C.; Du, D.; Zhang, L.; Mustafa, S.; Hameed, F.; Khan, M.R.; Zaheer, M.; Blaise, D. Petrography and provenance of the Early Miocene Murree Formation, Himalayan Foreland Basin, Muzaffarabad, Pakistan. J. Asian Earth Sci. 2018, 162, 25-40. [CrossRef]

27. Razzaq, S.S. Structural Geometry and Kinematic Analysis of Jhelum Fault, Hazara Kashmir Syntaxis, Northwest Himalayas, Pakistan. Master's Thesis, University of Azad Jammu and Kashmir, Muzaffarabad, 2013.

28. DeCelles, P.; Kapp, P.; Gehrels, G.; Ding, L. Paleocene-Eocene foreland basin evolution in the Himalaya of southern Tibet and Nepal: Implications for the age of initial India-Asia collision. Tectonics 2014, 33, 824-849. [CrossRef]

29. Jagoutz, O.; Schmidt, M. The formation and bulk composition of modern juvenile continental crust: The Kohistan arc. Chem. Geol. 2012, 298, 79-96. [CrossRef]

30. Bouilhol, P.; Jagoutz, O.; Hanchar, J.M.; Dudas, F.O. Dating the India-Eurasia collision through arc magmatic records. Earth Planet. Sci. Lett. 2013, 366, 163-175. [CrossRef]

31. Searle, M.; Khan, M.A.; Fraser, J.; Gough, S.; Jan, M.Q. The tectonic evolution of the Kohistan-Karakoram collision belt along the Karakoram Highway transect, north Pakistan. Tectonics 1999, 18, 929-949. [CrossRef]

32. Petterson, M.G. A review of the geology and tectonics of the Kohistan island arc, north Pakistan. Geol. Soc. Lond. Spec. Publ. 2010, 338, 287-327. [CrossRef]

33. Jan, M.; Karim, A. Coronas and high-P veins in metagabbros of the Kohistan island arc, northern Pakistan: Evidence for crustal thickening during cooling. J. Metamorph. Geol. 1995, 13, 357-366. [CrossRef]

34. Jan, M.Q.; Khan, M.A.; Qazi, M.S. The Sapat mafic-ultramafic complex, Kohistan arc, North Pakistan. Geol. Soc. Lond. Spec. Publ. 1993, 74, 113-121. [CrossRef]

35. Khan, M.A.; Jan, M.Q.; Weaver, B. Evolution of the lower arc crust in Kohistan, N. Pakistan: Temporal arc magmatism through early, mature and intra-arc rift stages. Geol. Soc. Lond. Spec. Publ. 1993, 74, 123-138. [CrossRef]

36. Treloar, P.J.; Petterson, M.G.; Jan, M.Q.; Sullivan, M. A re-evaluation of the stratigraphy and evolution of the Kohistan arc sequence, Pakistan Himalaya: Implications for magmatic and tectonic arc-building processes. J. Geol. Soc. 1996, 153, 681-693. [CrossRef]

37. Tahirkheli, R.K.; Mattauer, M.; Proust, F.; Tapponnier, P. The India Eurasia suture zone in northern Pakistan: Synthesis and interpretation of recent data at plate scale. Geodyn. Pak. 1979, 125-130.

38. Treloar, P.J.; Coward, M.P. Indian Plate motion and shape: Constraints on the geometry of the Himalayan orogen. Tectonophysics 1991, 191, 189-198. [CrossRef]

39. DiPietro, J.A.; Pogue, K.R. Tectonostratigraphic subdivisions of the Himalaya: A view from the west. Tectonics 2004, 23, 1-20. [CrossRef]

40. Kaneko, Y.; Katayama, I.; Yamamoto, H.; Misawa, K.; Ishikawa, M.; Rehman, H.; Kausar, A.; Shiraishi, K. Timing of Himalayan ultrahigh-Pressure metamorphism: Sinking rate and subduction angle of the Indian continental crust beneath Asia. J. Metamorph. Geol. 2003, 21, 589-599. [CrossRef]

41. Bossart, P.; Ottiger, R. Rocks of the Murree Formation in northern Pakistan: Indicators of a descending foreland basin of late Paleocene to middle Eocene age. Eclogae Geol. Helv. 1989, 82, 133-165.

42. Singh, B. Evolution of the Paleogene succession of the western Himalayan foreland basin. Geosci. Front. 2013, 4, 199-212. [CrossRef]

43. Gansser, A. Geology of the Himalayas; Interscience Publisher, John Wiley: New York, NY, USA, 1964.

44. Bossart, P.; Dietrich, D.; Greco, A.; Ottiger, R.; Ramsay, J.G. The tectonic structure of the Hazara-Kashmir Syntaxis, southern Himalayas, Pakistan. Tectonics 1988, 7, 273-297. [CrossRef]

45. Ingersoll, R.V.; Fullard, T.F.; Ford, R.L.; Grimm, J.P.; Pickle, J.D.; Sares, S.W. The effect of grain size on detrital modes; a test of the Gazzi-Dickinson point-counting method. J. Sediment. Res. 1984, 54, 103-116. [CrossRef]

46. Dickinson, W.R. Interpreting provenance relations from detrital modes of sandstones. In Provenance of Arenites; Springer: Berlin/Heidelberg, Germany, 1985; pp. 333-361. [CrossRef]

47. Corfu, F.; Hanchar, J.M.; Hoskin, P.W.; Kinny, P. Atlas of zircon textures. Rev. Mineral. Geochem. 2003, 53, 469-500. [CrossRef]

48. Fornelli, A.; Festa, V.; Micheletti, F.; Spiess, R.; Tursi, F. Building an Orogen: Review of U-Pb Zircon Ages from the CalabriaPeloritani Terrane to Constrain the Timing of the Southern Variscan Belt. Minerals 2020, 10, 944. [CrossRef]

49. Sláma, J.; Košler, J.; Condon, D.J.; Crowley, J.L.; Gerdes, A.; Hanchar, J.M.; Horstwood, M.S.; Morris, G.A.; Nasdala, L.; Norberg, $\mathrm{N}$. Plešovice zircon-A new natural reference material for U-Pb and Hf isotopic microanalysis. Chem. Geol. 2008, $249,1-35$. [CrossRef]

50. Spencer, C.J.; Kirkland, C.L.; Taylor, R.J. Strategies towards statistically robust interpretations of in situ U-Pb zircon geochronology. Geosci. Front. 2016, 7, 581-589. [CrossRef]

51. Ludwig, K. Isoplot/Ex 3. In A Geochronological Toolkit Microsoft Excel. Berkeley Geochronology Center; Special Publication: Berkeley, CA, USA, 2003

52. Fernández-Suárez, J.; Gutiérrez-Alonso, G.; Jenner, G.; Tubrett, M. New ideas on the Proterozoic-Early Palaeozoic evolution of NW Iberia: Insights from U-Pb detrital zircon ages. Precambrian Res. 2000, 102, 185-206. [CrossRef]

53. Gehrels, G.; Kapp, P.; DeCelles, P.; Pullen, A.; Blakey, R.; Weislogel, A.; Ding, L.; Guynn, J.; Martin, A.; McQuarrie, N. Detrital zircon geochronology of pre-Tertiary strata in the Tibetan-Himalayan orogen. Tectonics 2011, 30, 1-27. [CrossRef] 
54. Fornelli, A.; Gallicchio, S.; Micheletti, F.; Langone, A. U-Pb detrital zircon ages from Gorgoglione Flysch sandstones in Southern Apennines (Italy) as provenance indicators. Geol. Mag. 2021, 158, 859-874. [CrossRef]

55. Rubatto, D. Zircon: The metamorphic mineral. Rev. Mineral. Geochem. 2017, 83, 261-295. [CrossRef]

56. Armstrong-Altrin, J.S. Detrital zircon U-Pb geochronology and geochemistry of the Riachuelos and Palma Sola beach sediments, Veracruz State, Gulf of Mexico: A new insight on palaeoenvironment. J. Palaeogeogr. 2020, 9, 1-27. [CrossRef]

57. Rubatto, D. Zircon trace element geochemistry: Partitioning with garnet and the link between U-Pb ages and metamorphism. Chem. Geol. 2002, 184, 123-138. [CrossRef]

58. Q Qasim, M.; Ding, L.; Khan, M.A.; Umar, M.; Jadoon, I.A.; Haneef, M.; Baral, U.; Cai, F.; Shah, A.; Yao, W. Late neoproterozoic-early Palaeozoic stratigraphic succession, western himalaya, north Pakistan: Detrital zircon provenance and tectonic implications. Geol. J. 2018, 53, 2258-2279. [CrossRef]

59. Naeem, M.; Burg, J.-P.; Ahmad, N.; Chaudhry, M.N.; Khalid, P. U-Pb zircon systematics of the Mansehra Granitic Complex: Implications on the early Paleozoic orogenesis in NW Himalaya of Pakistan. Geosci. J. 2016, 20, 427-447. [CrossRef]

60. Sajid, M.; Andersen, J.; Rocholl, A.; Wiedenbeck, M. U-Pb geochronology and petrogenesis of peraluminous granitoids from northern Indian plate in NW Pakistan: Andean type orogenic signatures from the early Paleozoic along the northern Gondwana. Lithos 2018, 318, 340-356. [CrossRef]

61. Rehman, H.U.; Yamamoto, H.; KHALIL, M.A.K.; Nakamura, E.; Zafar, M.; Khan, T. Metamorphic history and tectonic evolution of the Himalayan UHP eclogites in Kaghan valley, Pakistan. J. Mineral. Petrol. Sci. 2008, 103, 242-254. [CrossRef]

62. Rehman, H.U.; Yamamoto, H.; Shin, K. Metamorphic P-T evolution of high-pressure eclogites from garnet growth and reaction textures: Insights from the Kaghan Valley transect, northern Pakistan. Isl. Arc 2013, 22, 4-24. [CrossRef]

63. Myrow, P.; Hughes, N.; Paulsen, T.; Williams, I.; Parcha, S.; Thompson, K.; Bowring, S.; Peng, S.-C.; Ahluwalia, A. Integrated tectonostratigraphic analysis of the Himalaya and implications for its tectonic reconstruction. Earth Planet. Sci. Lett. 2003, 212, 433-441. [CrossRef]

64. Cawood, P.A.; Johnson, M.R.; Nemchin, A.A. Early Palaeozoic orogenesis along the Indian margin of Gondwana: Tectonic response to Gondwana assembly. Earth Planet. Sci. Lett. 2007, 255, 70-84. [CrossRef]

65. Aikman, A.B.; Harrison, T.M.; Lin, D. Evidence for Early (>44 Ma) Himalayan Crustal Thickening, Tethyan Himalaya, southeastern Tibet. Earth Planet. Sci. Lett. 2008, 274, 14-23. [CrossRef]

66. Myrow, P.M.; Hughes, N.C.; Goodge, J.W.; Fanning, C.M.; Williams, I.S.; Peng, S.; Bhargava, O.N.; Parcha, S.K.; Pogue, K.R. Extraordinary transport and mixing of sediment across Himalayan central Gondwana during the Cambrian-Ordovician. Geol. Soc. Am. Bull. 2010, 122, 1660-1670. [CrossRef]

67. Ding, L.; Maksatbek, S.; Cai, F.; Wang, H.; Song, P.; Ji, W.; Xu, Q.; Zhang, L.; Muhammad, Q.; Upendra, B. Processes of initial collision and suturing between India and Asia. Sci. China Earth Sci. 2017, 60, 635-651. [CrossRef] 